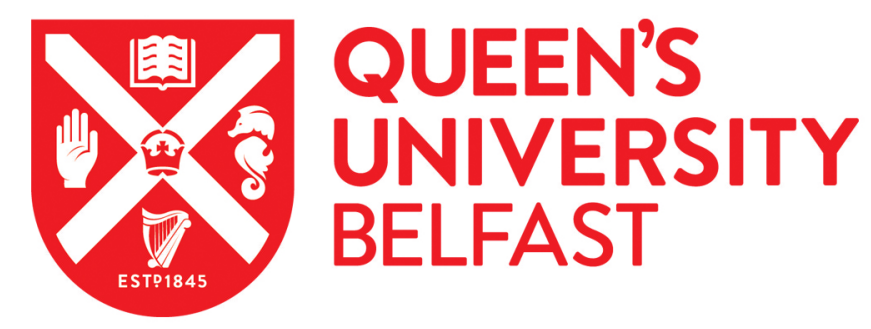

\title{
Rebalancing and Regional Economic Performance: Northern Ireland in a Nordic Mirror
}

Brownlow, G., \& Birnie, E. (2018). Rebalancing and Regional Economic Performance: Northern Ireland in a Nordic Mirror. Economic Affairs, 38(1), 58-73. https://doi.org/10.1111/ecaf.12267

\author{
Published in: \\ Economic Affairs
}

Document Version:

Peer reviewed version

Queen's University Belfast - Research Portal:

Link to publication record in Queen's University Belfast Research Portal

Publisher rights

(C) 2018 Institute of Economic Affairs. This work is made available online in accordance with the publisher's policies. Please refer to any applicable terms of use of the publisher

\section{General rights}

Copyright for the publications made accessible via the Queen's University Belfast Research Portal is retained by the author(s) and / or other copyright owners and it is a condition of accessing these publications that users recognise and abide by the legal requirements associated with these rights.

Take down policy

The Research Portal is Queen's institutional repository that provides access to Queen's research output. Every effort has been made to ensure that content in the Research Portal does not infringe any person's rights, or applicable UK laws. If you discover content in the Research Portal that you believe breaches copyright or violates any law, please contact openaccess@qub.ac.uk. 


\title{
Rebalancing and Regional Economic Performance: Northern Ireland in a Nordic Mirror
}

\begin{abstract}
(98 words)
Northern Ireland has been characterised as having an excessively large public sector. This characterisation has led some to explain poor regional economic performance in terms of 'crowding out'. This diagnosis has been used to justify a policy of 'rebalancing' and the region copying its southern neighbour's lower rate of corporation tax. However, Rodrik's comparative institutional analysis indicates that - as in the Nordics - a large public sector was the result of building a successful tradable private sector. In terms of the possible 'economic dividend' from devolution it suggests that a Hayekian insight is better: no 'silver bullets' exist.
\end{abstract}

Keywords: Rebalancing, Nordics, Northern Ireland, Institutions, Devolution

...it is the character rather than the volume of government activity that is important. A functioning market economy presupposes certain activities on the part of the state; there are some other such activities by which its functioning will be assisted; and it can tolerate many more, provided that they are of the kind which are compatible with a functioning market. But there are those which run counter to the very principle on which a free system rests and which must therefore be altogether excluded if such a system is to work. In consequence, a government that is comparatively inactive but does the wrong things may do much more to cripple the forces of a market economy than one that is more concerned with economic affairs but confines itself to actions which assist the spontaneous forces of the economy (Hayek 1960,.222).

Is it always the case though that a large public sector equates to a lack of economic competitiveness? Take somewhere like Sweden. $51.3 \%$ of its GDP is accounted for by public spending and nearly $40 \%$ of its people are employed in the public sector. Yet it ranks as the 5th most competitive economy on the planet and the most innovative. The same is true in places like Denmark, Finland and Singapore. Large public sectors and competitive economies aren't mutually exclusive (Hamilton 2013). 


\section{Introduction}

Hayek's political, legal and economic thought all share a number of common themes underpinned by a commitment to a free society (Friedman, 1977; Dietze, 1977; Butler, 1983; Vaughn, 1998). One clear theme that pervades Hayek's thinking across disciplinary boundaries, and perhaps best exemplified by the range of topics covered in his Individualism and Economic Order, is that of the advantages of decentralisation in both political and economic life (Hayek, 1948). Equally, Hayek was critical throughout his work of the idea that since humans created institutions (such as law and moral codes) they could easily alter them to satisfy desires or wishes (Butler, 1983). Likewise, another pervasive theme - of particular relevance to discussing rebalancing economies - concerns Hayek's insight on the size and scope of the state. This was the topic raised in The Road to Serfdom developed in the The Constitution of Liberty and refined further in Law, Legislation and Liberty (Butler, 1983, p.121).

While Hayek clearly favoured markets, due to their spontaneous ordering and discovery process features, he was no advocate of anarcho-capitalism; nor did he have much time for state monopolies (Hayek, 1982; Butler, 1983). Hayek thought was actually more nuanced than these ideological extremes: he instead argued that state intervention (with its attendant risk of government failure) could work under certain circumstances, but that the danger was that distortionary interventions - such as prices and wage controls - would harm the market process. Along these lines Hayek's Road to Serfdom has been reinterpreted as providing a government failure framework applicable to both markets and constitutions (Hayek, 1944; Boettke, 1995).

Hayek was particularly concerned that vested interests would hinder the market process; this led him to consider the possibility of creating a model constitution (Hayek, 1982). Hayek's discussion of a model constitution - as it was more concerned with more abstract issues concerning voting rights, constitutional courts and the failings of existing models - understandably gives very little concrete advice to fiscal aspects in the area of UK devolution. However, applying insights derived from both his earlier and later work provides clues. Hayek connected the issue of the size and scope of the state to the economics of political and fiscal decentralisation (Hayek, 1948, 1982).

In the wake of the economic and financial crisis of 2007-8 there has been recent popular discussion of the appropriate role of the state within modern economies. Authors vary on the consequences of different public spending shares and the respective merits of allowing the state rather than the market to perform different functions. A range of issues, that relate to the optimal balance between the private and public sector, including models of public sector delivery, regional and industrial policies have been reassessed in response to challenging economic conditions (Moretti 2013; Mazzucato 2013; Micklethwait and Woolridge 2014). Rebalancing, as discussed in the UK coalition government's 2010 Programme for Government (and reiterated in subsequent Budgets and Autumn Statements), reflected the diagnosis that economic performance in the years prior to the 
financial crisis had become too structurally and geographically dependent on the London and South East-based financial sector. Rebalancing, as outlined in Figure 1, thus involves a number of policy choices that all stem from trying to make the UK a less geographically and structurally skewed economy (Pike et al 2012).

\section{[Insert Figure 1 here]}

This ongoing debate on the merits of rebalancing, however it is defined, can be traced back to policy debates during the 1980s associated with the Thatcherite project of 'rolling back the frontiers of the state'. An important line of argument that re-emerges in rebalancing debate, as well as arguably explaining the Conservative Party approach to public expenditure after 1979, is associated with Bacon and Eltis (1976). They explained deindustrialization in the UK as being due to it being displaced ('crowded out') by the excessive growth of the non-market public sector, much of which consisted of nationalised industries such as steel. The growth of the non-market public sector relative to market sector, according to Bacon and Eltis, promoted higher taxation, interest rates, deterred investment and reduced international competitiveness (Crafts 2012).

However, economic historians (both sympathetic and unsympathetic to the economic reforms of the 1980s) have downplayed the relevance of the Bacon and Eltis mechanism in their analysis of the UK (Stafford, 1981; Crafts, 1993). It has been noted for instance that the rise in government-financed non-market sector consumption displaced market sector consumption rather than investment. Over time the number of workers paying income tax grew (Crafts, 1993, p.27). Furthermore, during the 1980s there was no decline in the relative size of the non-marketed sector, but the profit squeeze evaporated and the share of profits in value-added reverted back to 1960 s levels (Crafts, 1993, p.27). ${ }^{1}$ Hayekian qualifications to the original Bacon and Eltis (macroeconomic line of argument) would qualify the role of aggregation in the framework (Machlup, 1977).

In this paper we are interested in the regional level of analysis and in particular the Northern Ireland (NI) context. NI is a small polity with longstanding relatively large government sector combined with weak economic performance - can be contrasted with the success of the Nordics. ${ }^{2}$ The Nordic countries (defined here as including Norway, Sweden, Finland and Denmark), as successful small open economies, have been able to reconcile large public sectors with good long-run economic performance. Table 1 indicates the divergent living standard record of NI (and indeed the UK) relative to the Nordics:

\section{[Insert Table 1 Here]}

Moreover, efficient Nordic economic outcomes have been reconciled with a fair degree of social equity. ${ }^{3}$ Acemoglu and Robinson (2014) have indeed claimed that institutional factors go most of the way in explaining Sweden's favourable egalitarian socio-economic outcomes. By extension, given the institutional analogies that will be demonstrated to exist amongst the Nordics, a similar assessment may arguably also apply to Denmark, Finland and Norway: in contrast, the history of Northern Irish political and economic institutions before the Troubles cannot be described as leading to egalitarian outcomes. The primary purpose of this article is to evaluate the claims that the Nordics provide a relevant economic-institutional model for NI to imitate or import. 
Hence, for those particularly interested in the possible connections between government expenditure and economic activity, NI provides an interesting institutionaleconomic 'mirror' in which to compare the Nordics against. 'Big government' has succeeded in the Nordics in a way that it has not in Northern Irish context. Political scientists have under a number of terms including 'policy transfer', considered the issue of the extent to which policies, institutions and concepts from one jurisdiction can be transplanted into another (Dolowitz and Marsh 1996; Dolowitz and Marsh 2000; Dolowitz and Medearis 2009). The policy relevance and implications of comparison with Nordics have not escaped political and business figures within NI (Hamilton 2013, Birnie 2014).

A supplementary purpose of this article is to demonstrate that a comparative institutional analysis of NI relative to the Nordics also has more general implications for those searching for an elusive 'economic dividend' from devolution in the UK (Pike et al 2012; Tomlinson 2014). Concerning the 'economic dividend' of devolution, devolution by itself has not led to an effective policy making. Indeed there has been some academic discussion about the willingness or ability of the devolved institutions to contribute to economic improvement (Murtagh and Shirlow 2012).

In contrast, to the influential 'crowding out' thesis, the oft-misrepresented ideas of Friedrich Hayek on the economic role of the state should be considered. Hayek's analysis has important implications for considering rebalancing in general and the more specific feasibility of transplanting the Nordic model elsewhere. ${ }^{4}$ In his Constitution of Liberty, Hayek argued that the vital issue was not the relative or absolute size of the public sector. $^{5}$ The essence for Hayek was that appropriate interventions (and hence the balance between the private and public sector) should be based on following rules rather than discretion. ${ }^{6}$ Moreover, Hayek did not think the volume and structure of appropriate interventions would remain constant. Of particular relevance to contemporary debates on policy transfer and/or public service delivery, he argued that technical change would 'constantly suggest new ways in which government might render services to its citizens and bring such possibilities within the range of the practicable' (Hayek 1960, p.231).

However, while Hayek's argument is more applicable than the Bacon and Eltis hypothesis, even it is incomplete. Gray argues perceptively that Hayek's analysis does not go far enough in terms of considering the institutional environment in which public policy operates, as markets are 'complex cultural institutions that are embedded in customs and traditions' (Gray 1998, 155). Hence an apparently well-functioning 'spontaneous' market actually requires the foundations of an informal as well as formal institutional system. Moreover, as cultures vary so there will be many forms of market economy 'and many species of capitalism' (Gray 1998, 155). This cultural-institutional or contextual dimension, which finds fruition in the 'varieties of capitalism' literature, is highly germane to the comparative institutional perspective developed later in the paper (Hall and Soskice 2001).

In section 2 the paper considers the issues that arise from trying to rebalance the NI economy. We then in section 3 consider to what extent the Nordic countries are alike. This is followed in section 4 by a consideration of how far the Nordic economies have changed in recent decades. Then in section 5 we consider how far any Nordic model could in fact be transferable. As part of that discussion we probe the issue of the institutional economics of devolution and make some observations regarding fiscal decentralisation in the context of the UK. And we conclude with section 6 . The evidence 
presented in this paper indicates that Northern Irish economic problems arise less from the public sector being too big and more that the private sector has been too weak; that NI has not yet developed a sufficiently large and thriving exporting and externally trading private sector. In short, NI has a relatively large public sector in part to compensate for a legacy of industrial decline and political instability. The paper concludes that comparative institutional analysis indicates that the parallels between the large public sectors of the Nordics and NI should not be overdrawn.

\section{Rebalancing and the NI economy}

Rebalancing in the NI case, however it is defined, did not automatically follow the introduction of devolution (HM Treasury 2011; Murtagh and Shirlow 2012). Claims that public sector dependence has damaged the NI economy are longstanding and they predate the introduction of the modern devolved political institutions. Gibson (1996) argued that one consequence of the relatively large public sector was that wage and benefit levels were pushed above those which would have been consistent with a full employment equilibrium. ${ }^{8}$

Yet whatever the merits of the 'crowding out' thesis as providing a diagnosis of long-run British economic performance, it cannot convincingly explain either the Nordic or Northern Irish experiences. ${ }^{9}$ The need to rebalance the NI economy on a variety of measures discussed in Figure 1 has been debated within official documents. HM Treasury in Rebalancing the Northern Ireland Economy explicitly linked the issue of rebalancing to the economic legacy of the Troubles (HM Treasury 2011). The opening paragraph of the report argued that violence had deterred private sector foreign investment, and that 'although helpful, peace has not in itself been sufficient to raise Northern Ireland prosperity to the UK average or even to the UK average excluding South East England' (HM Treasury 2011). The Treasury's analysis then equated any move towards creating a relatively smaller public sector in the NI context with a reduced corporation tax rate encouraging increased inward investment.

However, there are other UK regions, notably Wales and the North East of England with relatively high percentages of public spending compared to regional GVA; about $65 \%$. This is suggestive that NI's position is partly the outcome of relative economic performance, relatively high rates of unemployment and relatively low rates of income per head, but partly it is also the outcome of relatively recent history. The HMT diagnosis notably presents the economic malaise of NI as being based on a syndrome unique to the region rather than representing a more general problem associated with the UK's (or indeed Europe's) peripheral and/or post-industrial regions.

On reflection, NI has long exhibited three classes of economic problem; none of these three classes of problem can be blamed plausibly on an excessively large public sector (Brownlow 2013; 2015). A first category of problems are the economic weaknesses that it has shared with Britain. Failures of macroeconomic policy can be placed in this category (Crafts 1995; 2012). A second category of weaknesses has involved magnified versions of weaknesses found in the rest of the UK such as weaknesses in training, limited management capabilities and an underdeveloped innovation system (Crafts 1995; Hitchens and Birnie 1994; Birnie and Hitchens 1999; Brownlow 2013). A third source of malaise have been those unique to the region's circumstances (Hitchens and Birnie 1994; Birnie and Hitchens 1999; Brownlow 2012). ${ }^{10}$ While acknowledging the way that a governmental 'regional Keynesian' policy response - initially to mitigate civil unrest and then to support a peace 
process - tended to boost public expenditure, it is still the case that the Treasury's analysis of rebalancing tended to overstate the importance of this third category. ${ }^{11}$ Therefore, the economic challenges facing NI are not entirely attributable to region-specific sources; instead they relate in large part to the UK's unbalanced spatial and structural economics (Pike et al 2012; Tomlinson 2012, 2014).

Private sector-led growth in the UK has become concentrated in London and the South East (Pike et al 2012). The market sector has thus become geographically concentrated in the English South East. In contrast, the poorer northern and western regions (a category in which we can place NI) have been stabilised only by the growth of nonmarket services being used to replace lost manufacturing output and employment (Pike et al 2012, pp.19-20; Tomlinson 2014). The stabilisation of fragile regional economies by increasing their dependence on public sector employment has created 'sheltered' regional economics across Europe (Rodríguez-Pose and Fratesi 2007). The need to rebalance the NI economy reflects the fact that the region (like many others in Europe) exhibits a wider issue of a weak, deglobalised private sector giving rise to a dependence on the public sector.

A simple Bacon and Eltis 'crowding out' diagnosis, a diagnosis that was after all developed to explain macroeconomic rather than regional economic performance, therefore is misleading in the context of the NI economy for at least three reasons. Firstly, levels of public expenditure, both per capita and as a percentage of regional GDP, have increased to a relatively high levels. ${ }^{12}$ To the extent that much of that government spending is funded by a fiscal transfer from the rest of the UK this may have implied a higher level of demand in the regional economy and hence higher private sector output. The simple percentage of public spending relative to regional GVA also does not allow for the extent to which parts of the NI private sector are also, indirectly, dependent on public expenditure (a mechanism that the simple 'crowding out' mechanism tends to ignore). There could in fact be a negative and multiplied effect throughout the private sector if public expenditure were reduced. The weakness of the private sector, which increases the region's economic reliance on public sector activity, reflects the fact that, unlike the Nordics, the region has exhibited longstanding structural weakness reflecting in part nationwide problems.

Secondly, the empirical evidence on government R\&D expenditures does not tend to support the 'crowding out' thesis. For a region like NI that has long lagged in terms of $\mathrm{R} \& \mathrm{D}$, a narrow focus on reducing public expenditure is unlikely to unleash enterprise, but a more careful targeting of spending to assist innovation in the private sector might help (Northern Ireland Economic Council 1999). The historical record of UK industrial policy suggests that the dangers associated with government failure (however defined) are very real (Shackleton and Zuluaga, 2016).

Evidence from NI service firms suggests that policy should aim to foster extra-regional consumers and innovation will be boosted if exports are the focus of policy (Love, Roper and Hewitt-Dundas 2010). Thirdly, in the NI case discussing the economy in terms of a clear public-private divide obscures the fact that a substantially publically funded community and voluntary sector exists; that social enterprises, particularly in disadvantaged urban communities, have important roles to play (Murtagh and Shirlow 2012).

\section{Nordics}


Norway, Sweden, Finland and Denmark are all small, open economies (each with populations of about $5 \mathrm{~m}$ although Sweden is rather larger at about $10 \mathrm{~m}$ ). They have some cultural similarities which is unsurprising given the various ways in which these nations were joined together in a variety of political unions over the last three or four centuries. At the same time, it is important not to exaggerate how far they are homogenous. For example, one of the four countries, Finland, is a Eurozone members and the other three are not, one is not in the European Union (Norway) and some approaches to policy differ. But have the Nordics really been so successful in economic terms? Table 1 suggests they have if the emphasis is on relative living standards and the employment rate (i.e. percentage of the working age population actually in work) although consideration of recent unemployment rates is more ambiguous. As Table 2 indicates, NI and the Nordics may not have shared outcomes in terms of living standards, but they have both developed large public sectors. ${ }^{13}$

\section{[Insert Table 2 Here]}

Throughout the twentieth century the four Nordic countries also maintained consistently democratic, parliamentary institutions with a strong and growing representation of women, alongside relatively egalitarian outcomes with respect to, say, educational performance and distribution of income. As noted in Table 3, according to the standard statistical measure of the extent of equality in incomes the Gini coefficient, the Nordics have been consistently some of the most equal of the OECD countries. ${ }^{14}$

\section{[Insert Table 3 Here]}

Economists emphasise a potential trade-off between economic efficiency (and competitiveness) on the one hand and equality on the other (Okun 1975). Different economists have different normative views of the implications of such a trade-off: Hayek's writings for instance can be interpreted as valuing the pursuit of efficiency over equity. In contrast, Stiglitz's more recent work indicates that greater equity may be necessary for dynamic efficiency as embodied in innovation (Stiglitz 2014). His argument appears to have strong support from Nordic empirical evidence. Significantly, the Nordics have scored well on both equality/quality of life measures as well, though probably to a lesser extent, on those relating to competitiveness. This is demonstrated in Table 4.

\section{[Insert Table 4 Here]}

Given all this, it is unsurprising that admiring glances at the Scandinavian countries started many years ago. In the 1930s some British and American commentators thought that Sweden had perfected a rather attractive "middle way" between instable capitalist systems characterised by mass unemployment and planned economies characterised by despotism although this Swedish variant of "Keynesianism" may have been better developed in theory than in practice until well after the Second World War. ${ }^{15}$

\section{Change within the Nordics}

A key shared characteristic of the Nordics is not that they escaped crisis: it is that they were more resilient. Challenges during the 1970s, 1980s and early 1990s produced resolute reform programmes, in Sweden this has involved cutting public expenditure, and now these 
countries are enjoying favourable outcomes. The NI economy and policy system have probably not been good at rising to challenges. It might be suggested that the 2010 Spending Review and subsequent Executive Budget and Programme for Government for 2011-15 were missed opportunities. Notwithstanding the global downturn, the Nordics were relatively successful in containing the rise in unemployment. This, obviously, is an attractive outcome. Importantly, it may be less that the Nordics have avoided crises and more that either they had their own crisis somewhat earlier than the rest of Europe or that they handled the response to the recent banking crisis better. Norway had to cope with a property and credit boom in the 1980s. In Finland unemployment rose to $20 \%$ following the loss of the traditionally very important export market in the former Soviet Union. Various forms of policy discipline were applied. For example, central banks in Sweden and Norway were amongst the first to move towards tough inflation targets. Finland became a member of the Eurozone.

The Nordics have also adopted a range of budget and budget deficit rules. Denmark has a renowned system of labour market "flexicurity". However, Denmark's labour market performance was not always favourable. In the 1970s there was considerable stagflation. It was only later that wage setters (e.g. the unions) began to practice wage moderation. Employees can now expect to have to move around as market conditions change and also to re-train if necessary. The flip side of this social contract is that they will be protected and the state will pay for the re-training etc. In other words, welfare benefits are high, which maintains equity, but employers still operate in a system geared to efficiency as they have strong rights to hire and fire (Boeri, Galasso and Conde-Ruiz 2012; World Bank 2012). ${ }^{16}$ Various commentators have argued for a Danish flexicurity system in UK, as it is suggested that it tends to promote a high-skilled, high-productivity and high-wage labour market. Given that NI has long had particular problems in this regard, so it might appear particularly attractive to policymakers at Stormont (Hutton 1994; Birnie and Hitchens 1999). A jurisdiction can of course choose to have active labour market policies similar to Denmark provided it is prepared to pay for them; in 2008 Denmark spent the equivalent of $2.6 \%$ of its GDP on active labour market policies compared to an OECD average rate of $1.4 \%$ (World Bank 2012, 298).

As noted in Section 2, consideration of rebalancing the NI economy often starts by looking at the size of public spending relative to the region's GVA or GDP. How do the Nordics perform in that regard? Here, the position is mixed but to the extent that the Scandinavian public sectors have got leaner this probably means that it is too simplistic to treat the Nordic example as a "get out of fail free card" for NI's heavy dependence on the public sector. In Sweden, for example, state spending relative to GDP peaked at $67 \%$ in 1993. A significant fiscal retrenchment then followed. Since then it is notable that state spending has declined relative to national income and in the mid 2010 s stood at about $49 \%$ (in other words, not dissimilar to the UK national average). It is also worth pointing out that the headline rate of corporation tax in Sweden at $22 \%$ is similar to that of the UK (including NI). So, there may be a case, Aslund argues to view Sweden as, "...a new conservative model" (The Economist 2013). At the same time, the top marginal tax rate in Sweden was still 57\% (though down from 84\% in 1983). Denmark has moved in the other direction, public spending relative to GDP increasing from 51\% in 2007 to 58\% in 2013. Norway's figure remained at 52\% (about one-third of public revenues come from North Sea oil receipts). 


\section{How Transferable is the Nordic Model? Some Observations Regarding Devolution Economics}

Rodrik's 1998 paper has important implications for observing a small open economy such as Northern Ireland in a Nordic mirror (Rodrik 1998). Rodrik's comparative institutional analysis thus helps shed further light on the possible transferability of the Nordic model. Rodrik observed the robust statistical coexistence of vibrant trading performance in small highly, open European economies, such as the Nordics, with some of the world's highest shares of government spending in national income. Rodrik argued that a compensation hypothesis explained the empirical findings (Rodrik 1998; Hardiman, Murphy and Burke 2008). Big government and high levels of openness, according to Rodrik, coexisted because societies demanded (and received) an expanded government role as the insurance 'premium' required for accepting a larger exposure to external trading risk. As he noted, 'government spending appears to provide social insurance in economies subject to external shocks' (Rodrik 1998, 998). Rodrik's compensation hypothesis implies that the inequities that can arise from an export-led pursuit of growth requires an institutional 'safety net'. Rodrik of course ignored the observation that some of this 'insurance' could be provided by the private or voluntary sector.

Rodrik's compensation hypothesis has proven influential within the applied economics and public finance literatures as well as inspiring work within political science (Anderson 2012; Boeri, Galasso and Conde-Ruiz 2012; Hardiman, Murphy and Burke 2008). Tomlinson's analysis of the long-run development of the Scottish economy also makes use of Rodrik's compensation hypothesis. Tomlinson's discussion is most germane to our discussion as it has relevance to another devolved region of the UK with an industrial legacy of shipbuilding and textiles that gave way to a process of deglobalisation based on an increased reliance on public sector employment (Tomlinson 2012, 2014). Tomlinson observes, with particular resonance to those search for an 'economic dividend' from devolution, that devolution reinforces de-globalisation. ${ }^{17}$ With the creation of devolved political institutions, decisions made about public expenditure within the Scottish Parliament, based on constraints imposed from London, increasingly matter more than before (Tomlinson 2014, 176). This paper indicates that, irrespective of the political uncertainties that exist, what is true for Edinburgh, also holds for Belfast. Furthermore, the gap between the devolution of expenditure and taxation is one only starting to narrow.

Earlier in the paper it was suggested that the institutional-cultural component is germane to discussing the Nordic model and the feasibility of transplanting it. The four Nordic countries are now politically independent of each other. Incidentally, three are in the EU and one (Norway) outside and one in the euro and three outside (Denmark, Sweden and Norway). They do retain many cultural similarities. They have been ethnically relatively homogenous, at least until the arrival of migrants and asylum seekers in recent years, are internationally orientated including being strongly connected into the English-speaking world, and have a sort of post-Lutheran communitarianism (The Economist 2013). ${ }^{18}$ It is not straightforward to compare and contrast social values and attitudes across countries. However, one attempt, the World Values Survey 1991-2001 suggests the Nordics combine an attachment to a strong state with radical individualism, 
i.e. a strong emphasis on individual autonomy and equality with the state seen as an instrument which helps achieve such outcomes (Inglehart and Welzel 2005).

By these standards, NI looks rather different, being insular, monolingual and still marred by many post-conflict divisions. A more positive readings of NI's position, if one values these things, as also indicated in Inglehart and Welzel (2005), is that NI people place relatively high dependence on family and traditional values. The Nordics economies do appear unusual, e.g. as indicated by surveys such as Eurobarometer, because they combine relatively high attachment to radical individualism with a high degree of trust in government and public institutions.

The four Nordics are often regarded as interesting laboratories in public policy. As places, in fact, where evidence based policy making is actually done. Interestingly for those social scientists interested in policy transfer, the London coalition government has shown some willingness to look to Nordic policy models, e.g. Swedish free schools. Perhaps the lesson for NI is that it is possible to have sophisticated policy making. However, to the extent that such sophistication brings a resource requirement, the challenge then would be is the Executive/Assembly willing to pay for that, indeed, given its existing (limited) powers of fiscal variation could it raise such resources?

There is room to debate just how socialist/social democratic social welfare, educational and other policies have been in the Nordics. But for sure such policy making has taken place alongside a highly competitive market orientated core in each Nordic economy. Equity has been reconciled with efficiency in a way that tends to confirm Rodrik's thesis (Rodrik 1998; Tomlinson 2014). One Danish pharma firm, for example, produces about one half of the world's insulin. In 2010 the enterprise department (DETI) commissioned studies as to how the innovation systems in Sweden and Finland worked (Oxford Economics 2011). One possible indication of the success of the approach taken in the Nordics is that to a much greater extent than the UK (including NI) they have maintained a relatively buoyant manufacturing sector. This suggests success in terms of being competitive in global markets. Table 5 illustrates some revealing comparative data:

\section{[Insert Table 5 Here]}

Not only do the Nordics tend to have larger manufacturing sectors in proportional terms but they invest and export more (the Nordic/UK comparison is subject to the caveat that small economies, generally, have higher exports to GDP ratios). They also invest more, in proportional terms, on business R\&D and have had much more buoyant manufacturing output growth over the last two decades. In placing such emphasis on the proportional scale of manufacturing we are not intending to make the argument "manufacturing good, service sectors bad". Moreover, as Scottish evidence indicates, it is questionable if calls to 'reindustrialise' UK regions would adequately address the important employment implications of such an aim (Tomlinson 2014, 177; Shackleton and Zuluaga, 2016). Some services, e.g. ICT, banking and finance, legal, business, creative, architectural and civil engineering and tourism, do export ( $\mathrm{PwC}$ 2013). However, the total size of the global market in traded services remains much smaller than that for manufactured goods. 
Whilst the data are incomplete, NI's total service exports are likely to be much be much smaller than manufacturing exports. Interestingly and notwithstanding the small size of each of the Nordics, their national governments have also been able to stand aside from protectionist policies which attempt to create so-called national champions. For example, in recent years the Stockholm government refused to bail out Saab and it allowed a Chinese take-over of Volvo. The recent struggles of Nokia illustrate the point which we made earlier that all economic models are provisional and somewhat fragile; today's economic success can become tomorrow's failure. Incidentally, Nokia in 2000 represented about $4 \%$ of the entire GDP of Finland. Translated into NI terms that would be equivalent to about $£ 1.2$ bn or about twice the local sales of Bombardier.

There are some world competitive firms present within the NI region. The problem is there are too few of them. The most recent survey suggests that NI's largest manufacturing employers (250 or more employees) account for around 60 per cent of all exports (ex-UK) (Department of Finance and Personnel, 2013). The study for DETI of successful, small economies noted how a cross-sectoral priority on innovation was a stand-out feature of Finland's economic achievement (Oxford Economics 2011). Much more important than any financial incentives to business innovation activity was the fact that public sector, universities and industries collaborate in a seamless way. ${ }^{19} \mathrm{NI}$ and Sweden et al each have relatively large public sectors but this 'headline' similarity may be deceptive in terms of economic outcomes and context -such a finding echoes Hayek's analysis.

In practice, there is a much large market/client focus within the Nordics. In Denmark and Norway private firms run some hospitals. Vouchers are used to produce a market amongst schools in Sweden and Denmark. Finland, admittedly, combines extremely impressive school results along with what we might call a state financed comprehensive system; at the same time, a sharp divide between academic and vocational education occurs at age 16 and Finnish teachers, whilst comparatively poorly paid by UK standards have been allowed much greater freedom from state regulation and interference.

In the Nordics, government tends to be highly accessible, e.g. strong use of egovernment. Much of spending and taxation is pushed down to the local government level. Perhaps even more importantly, it is generally trusted; "The state is popular not because it is big but because it works" (The Economist 2013). It is also worth emphasising, again, how much and how well the state and private sectors collaborate. Yes, but only to a limited extent, it will be hard work to process the transfer and it will certainly take some time. For example, NI does not enjoy the full range of cultural values which underpin the Nordic model. The Executive in NI could adopt a much more Nordic evidence-based approach to policy making. Similarly, it could try to turn crisis into an opportunity although previous experience suggests little appetite for this. Whilst the Nordics have been successful in creating and maintaining very competitive private sectors this has remained the elusive goal for NI economic policy for several decades now.

Of course one need not look to the Nordics for policy transfer. Given the economic success of NI's southern neighbour (a success that has been in part attributed to lower corporate taxation) there have been calls, which can be traced back to the 1990s, to reduce the rate of Corporation Tax in NI relative to GB (PriceWaterhouseCoopers, 2011). So advocates of this policy take the distinctly non-Hayekian line that such tax reduction will act as a "silver bullet" that will rectify NI's economic weaknesses. The intellectual merits or otherwise of this proposal could justify a paper in their own right and indeed 
have already been much debated by academic, business and policy economists (PriceWaterhouseCoopers, 2011; Budd, 2016; Birnie and Brownlow, 2017). It is suffice to note that substantial political and business lobbying has gone into promoting the policy as a "silver bullet". The comments here, rather than arguing over the plausibility of the claim that lower taxation in isolation will create a step improvement in the NI economy, will instead merely note the institutional or legal complexities.

Devolving any tax rate varying power must satisfy the European Court of Justice (ECJ) regarding the "Azores case". The origins of this case were that in 1999 the Government of the Autonomous Region of the Azores adopted rules to reduce tax rates in the Azores relative to the rest of Portugal. The European Commission initiated a formal investigation because it was thought that such a rule violated state aid rules. The case was considered by the Constitutional Court of the ECJ. The ECJ ruled that the Azores did breach selective aid rules as reduced tax revenues were offset by mechanism that involved a budgetary transfer from the Portuguese government. The court held that the European Commission was correct to classify the Azores financial arrangements as selective and incompatible aid.

Of relevance to tax devolution in NI, the ECJ ruling sets out the three criteria (institutional autonomy, procedural autonomy and fiscal autonomy) which need to be met for regional variation in in direct taxation not to involve State Aid. Meeting all three criteria is required if a proposed tax devolution measure is to be compliant with EU law. The Treasury decided that NI met the first two of these conditions. However, to satisfy the fiscal autonomy condition, the NI Executive would need to bear the full fiscal consequences of changes in tax revenues resulting from a new (lower) NI corporation tax rate. In practical terms the Treasury required that Northern Ireland's block grant would be adjusted to reflect the fiscal costs of a reduced rate of Corporation Tax. Despite Brexit, and its associated legal changes, it is plausible to suggest that this fiscal implication will hold if CT is ever devolved.

\section{Conclusions}

The policy diagnoses of this paper are partly Hayekian, in the sense that following the arguments in Constitution of Liberty, and elsewhere, it has been more concerned with studying if and how the NI economy can be 'nudged' onto a more competitive ('Nordic') path, or if and how policies can be transferred, rather than focusing on a simple 'crowding out' analysis of governmental role in the economy. However, Hayek's analysis does not take us as far in the comparative institutional-cultural direction as we would wish. As Acemoglu and Robinson (2014) have demonstrated, institutional factors are crucial to explaining the fate of Swedish (and thus by extension, Nordic) economic performance. The paper therefore, while accepting Hayek's perceptive insight on the relative economic importance of the structure and volume of government, takes the analysis more along Rodrik's comparative institutional line of argument.

The Nordic countries have managed to combine relatively big states and successful economies. This shines an interesting light on recent debates about rebalancing the NI economy. At the same time, it cannot simply be assumed that because Denmark, Finland, 
Norway and Sweden manage to combine a large state sector with a vibrant economy that the same analysis should hold for NI. The Nordics have organised both their public and private sectors such that the large measured share of public sector activity is sustainable. The Nordics have managed to successfully balance equity and efficiency concerns. This is the challenge which NI has hitherto struggled with. At a superficial level, NI appears like the Nordics to have a performance culture in the public sector but in practice successful implementation of this has remained elusive. Some Nordic lessons are germane for NI. However, transplanting policies that emerged from within the Nordic cultural-institutional system may not be possible in the very different Northern Irish situation.

Rodrik's analysis indicates that what sets NI apart is not so much a large government sector, which as he notes lots of successful small open economies possess, instead what really sets NI apart is that a large public sector share does not correspond with a thriving, diverse export sector. In this regard, the failure to reverse de-globalisation and create a diversified, open economy in NI looks similar to the economic issues facing Scotland (Tomlinson 2012, 2014). Rebalancing is thus something desirable if it is generated by a transformation in regional competitiveness, but Rodrik's analysis implies that the standard idea, implicit in much of the rebalancing discussion, of a trade-off between more rapid growth (an efficiency measure) and higher levels of social protection (an equity measure) may be unhelpful (Tomlinson 2014, 175). As Tomlinson notes, it may actually be the case that 'higher levels of security remove resistance to growth-enhancing changes' (Tomlinson 2014, 175). 


\section{Bibliography}

Acemoglu, D and J. Robinson. (2014). The Rise and Fall of General Laws of Capitalism,

Working Paper, Massachusetts Institute of Technology, Cambridge, MA.

Anderson, J. (2012). Costs of taxation and the size of government. Public Choice, 153 (1\&2):

83-115.

Bacon, R. and W. Eltis. (1976). Britain's Economic Problem -Too Few Producers. Basingstoke: Macmillan.

Birnie, E. (2014). Is Northern Ireland ready to embrace the Nordics? Agenda NI Magazine,

Retrieved from http://www.agendani.com/is-northern-ireland-ready-to-embrace-the-nordics [7 February 2017].

Birnie, E. and D. Hitchens. (1999). Northern Ireland Economy: Performance, Prospects. Policy, Avebury: Ashgate.

Birnie, E. and G. Brownlow. (2017). Should the Fiscal Powers of the Northern Ireland Assembly be Enhanced'? Regional Studies 51 (9): 1429-1439.

Boeri, T., V. Galassso and J. Conde-Ruiz, (2012). The political economy of flexicurity. Journal of the European Economic Association, 10 (4): 684-715.

Boettke, P. (1995). Hayek's the Road to Serfdom Revisited: Government Failure in the Argument against Socialism. Eastern Economic Journal, 21 (1): 7-26. 
Brownlow, G. (2012). Towards an acceptable level of violence: institutional lessons from Northern Ireland. Terrorism and Political Violence, 24 (5): 722-742.

Brownlow, G. (2013). Business and labour since 1945, in L. Kennedy and P. Ollerenshaw Eds, Ulster since 1600: Politics, Economics and Society (pp.291-308). Oxford: Oxford University Press.

Brownlow, G. (2015). Back to the Failure: an analytic narrative on the DeLorean debacle. Business History, 57, 156-181.

Brownlow, G. (2017). Practice Running Ahead of Theory? Political Economy and the Economic Lessons of UK Devolution', Cambridge Journal of Regions, Economy and Society 10 (3): 559-573.

Budd, L. (2016). Economic Challenges and Opportunities of Devolved Corporate Taxation in Northern Ireland, in D. Bailey and L. Budd Eds, Devolution and the UK Economy (pp. 95115). London: Rowman \& Littlefield.

Butler, E. (1983). Hayek: His contribution to the Political and Economic Thought of our Time, London: Temple Smith.

Cairney, P. (2009). The role of ideas in policy transfer: the case of UK smoking bans since devolution, Journal of European Public Policy, 16 (3), 471-488.

Childs, M. (1947). Sweden: The Middle Way, New Haven: Yale University Press.

Crafts, N. (1993). Can De-Industrialisation Seriously Damage Your Wealth? A Review of Why Growth Rates Differ and How to Improve Economic Performance, London: Institute of Economic Affairs. 
Crafts, N. (1995). The Golden Age of economic growth in postwar Europe: why did Northern Ireland miss out?, Irish Economic and Social History, 22, 5-25.

Crafts, N, (2012). “British Relative Economic Decline Revisited: The Role of Competition.”, Explorations in Economic History, 49, (1): 17-29.

Department of Finance and Personnel. (2012). Northern Ireland Net Fiscal Balance Report 2009-10 and 2010-11, Bangor: DFP.

Department of Finance and Personnel. (2013). Results from the Northern Ireland Manufacturing Sales \& Exports Survey, 9 December, Bangor: DFP.

Davenport, M, (2014). Corporation tax: carrot or stick? BBC News, 3 December 2014

Retrieved from http://www.bbc.co.uk/news/uk-northern-ireland-30317230 [7 February 2017].

Dietze, G. 1977. Hayek on the Rule of Law, in F. Machlup Ed, Essays on Hayek (107-147). London: Routledge \& Kegan Paul.

Dolowitz, D and D. Marsh. (1996). Who learns what from whom: a review of the policy transfer literature. Political Studies, 44, (2), 343-357.

Dolowitz, D and D. Marsh. (2000). Learning from abroad: the role of policy transfer in contemporary policy-making, Governance 13 (1), 5-24.

Dolowitz, D and and D. Medearis. (2009).Considerations of the obstacles and opportunities to formalizing cross-national policy transfer to the United States: a case study of the transfer of urban environmental and planning policies from Germany. Environment and Planning C: Government and Policy, 27 (4), 684-697. 
Dunford, M and R. Hudson. (1996). Successful European Regions: Northern Ireland Learning From Others, Northern Ireland Economic Council Research Monograph 3, Belfast: Northern Ireland Economic Council.

The Economist. (2013). “The Next Supermodel”, February 2nd 2012.

Economic Advisory Group (EAG). (2011). The impact of Reducing Corporation Tax on the Northern Ireland Economy, Belfast: Economic Advisory Group.

Friedman, M. 1977. Foreword in F. Machlup Ed, Essays on Hayek (xxi). : London: Routledge \& Kegan Paul.

Gamble, A. (1996). Hayek and the Iron Cage of Liberty. London: Polity Press.

Gibson, N. (1996). Northern Ireland and Westminster: fiscal decentralisation a public economics perspective, in Northern Ireland Economic Council eds, Decentralised Government and Economic Performance in Northern Ireland, Occasional Paper 7 (pp.1089), Belfast: Northern Ireland Economic Council.

Gray, J (1998). Hayek on Liberty. $3^{\text {rd }}$ Edition, London: Routledge.

Hall, P and D. Soskice (eds). (2001). Varieties of Capitalism: the Institutional Foundations of Comparative Advantage, Oxford: Oxford University Press.

Hamilton, S. (2013, Thursday 1st). Minister Department of Finance and Personnel Speech to CBI Northern Ireland, CBI Northern Ireland Event, Belfast.

Hardiman, N, P, Murphy and O, Burke, 2008. The politics of economic adjustment in a liberal market economy, Irish Political Studies, 23 (4), 599-626.

Hayek, F. (1944). The Road to Serfdom, London: Routledge. 
Hayek, F. (1948). Individualism and Economic Order, London: Routledge.

Hayek, F. (1960). The Constitution of Liberty. London: Routledge Kegan Paul.

Hayek, F. (1982). Law, Legislation and Liberty. London: Routledge Kegan Paul.

Hinds, J and P. Holingsworth. (2014). Finland set to lag behind Nordic neighbours, European Economics Focus, London: Capital Economics.

Hitchens, D., K. Wagner and E. Birnie. (1990). Closing the Productivity Gap: A Comparison of Northern Ireland, The Republic of Ireland, Britain and West Germany. Aldershot: Avebury.

Hitchens, D. and E. Birnie. (1994). The Competitiveness of Industry in Ireland. Aldershot: Avebury.

Hutton, W. (1994). Britain and Northern Ireland, The State We're In-Failure and Opportunity, Charles Carter Lecture, Paper 114, Belfast: Northern Ireland Economic Council. Inglehart, R, and C, Welzel. (2005). Modernization, Cultural Change and Democracy: The Human Development Sequence. Cambridge: Cambridge University Press.

Love, J, S. Roper and N, Hewitt-Dundas, (2010). Service innovation, embeddedness and business Performance: evidence from Northern Ireland. Regional Studies, 44 (8), 983-1004.

Machlup, F. (1977). Hayek's Contribution to Economics in F. Machlup Ed, Essays on Hayek (13-61). London: Routledge \& Kegan Paul.

Mazzucato, M. (2013). The Entrepreneurial State: Debunking Public Vs. Private Sector Myths. London: Anthem Press. 
McGregor, P. and V. Borooah. (1991). Poverty and distribution of income and poverty in Northern Ireland, Economic and Social Review, 22 (2), 81-100.

Micklethwait, J and A, Woolridge. (2014). The Fourth Revolution: the Global Race to Reinvent the State. London: Allen Lane.

Miller, E. (2010). Hayek's Constitution of Liberty: an Account of its Argument. London: Institute of Economic Affairs.

Moretti, E. (2012). The New Geography of Jobs. New York, NY: Houghton Mifflin Harcourt. Murtagh, B. and P. Shirlow (2012). Devolution and politics of development in Northern Ireland. Environment and Planning C: Government and Policy, 30 (1), 46-61.

Mjøset, L. (1992). The Irish Economy in Comparative Institutional Perspective. PL 8967, Dublin: National Economic and Social Council.

Northern Ireland Economic Council. (1999). Publicly Funded R\&D and Economic Development in Northern Ireland, Report 133, Belfast: Northern Ireland Economic Council.

Okun, A. (1975). Equality and Efficiency: The Big Tradeoff. Washington, D.C: The Brookings Institution.

Office for National Statistics. (2013). "Regional GVA (Income Approach) December 2013", Statistical Bulletin, ONS, Newport, Retrieved from http://www.ons.gov.uk/ons/dep171778_345191.pdf [18 December 2013].

Oxford Economics. (2011). Building economic competitiveness: Lessons from small peripheral European states- Overview report, A report commissioned by DETI, Department of Enterprise, Trade and Investment. Belfast: DETI. 
Pike, A, A, Rodríguez-Pose, J. Tomaney, G, Torrisis, and Tselios, V. (2012). In Search of the 'economic dividend' of devolution: spatial disparities, spatial economic policy, and decentralisation in the UK. Environment and Planning C: Government and Policy, 30 (1), 1028.

PriceWaterhouseCoopers LLP. (2011) Corporation Tax: Game changer or game over? Government Futures, Belfast: PwC.

PriceWaterhouseCoopers LLP. (2013). UK Economic Outlook, November 2013, London: PwC.

Quigley, G, 1976. Economic and Social Strategy for Northern Ireland Report by Review Group. Belfast: Her Majesty's Stationary Office.

Rodríguez-Pose, A. and N, Gill (2005). On the 'economic dividend' of devolution. Regional Studies, 39,(4), 405-420.

Rodríguez-Pose, A. and U, Fratesi. (2007). Regional Business Cycles and the Emergence of Sheltered Economies in the Southern Periphery of Europe. Growth and Change, 38, 4, 621648.

Rodrik, D. (1998). Why do more open economies have bigger governments? Journal of Political Economy, 106 (5), 997-1033.

Rowthorn, B. (1981). Northern Ireland: an economy in crisis Cambridge Journal of Economics, 5 (1), 1-31.

Shackleton, J.R. and Zuluaga, D. (2016) Balancing the Economy: the hand of government or the invisible hand? London: Institute of Economic Affairs.

Stafford, G.B. (1981). The End of Economic Growth? Growth and Decline in the UK since 1945, Oxford: Martin Robertson. 
Stiglitz, J. (2014). Leaders and followers: perspectives on the Nordic model and the economics of innovation, Cambridge, MA: National Bureau of Economic Research, WP 20493.

Tomlinson, J (2012). De-Globalization and its Significance: From Particular to the General. Contemporary British History, 26 (2), 213-230.

Tomlinson, J, (2014). Imagining the Economic Nation: the Scottish Case. The Political Quarterly, 85 (2), 170-177.

HM Treasury. (2011). Rebalancing the Northern Ireland Economy. London: HM Treasury.

Trench, A. (2013). Funding Devo More: fiscal options for strengthening the union. London: Institute for Public Policy Research.

Vaughn, K. (1998). Austrian Economics in America: The Migration of a Tradition. Cambridge: Cambridge University Press.

World Bank. (2012). Golden Growth: Restoring the Lustre of the European Economic Model. Washington DC: World Bank. 
Figure 1: Options as to how to measure the rebalancing of the NI economy

\begin{tabular}{lll}
\hline Aspect of rebalancing & Options \\
\hline - Public spending & $\begin{array}{l}\text { Absolute amount, real terms or cash } \\
\text { terms?, OR as a percentage of total } \\
\text { GVA? }\end{array}$ \\
\hline $\begin{array}{l}\text { Public sector employment } \\
\text { - Timescale of adjustment }\end{array}$ & $\begin{array}{l}\text { Absolute number OR as a percentage } \\
\text { of total employment? }\end{array}$ \\
\hline $\begin{array}{l}\text { Size of the fiscal transfer, or subvention, from } \\
\text { HM Treasury to the Executive to cover the } \\
\text { excess of public spending compared to tax }\end{array}$ & $\bullet \quad \begin{array}{l}\text { Is reduction in the transfer part of } \\
\text { rebalancing OR not? }\end{array}$ \\
\hline
\end{tabular}
receipts in $\mathrm{NI}^{20}$ 
Table 1: Relative living standards and labour market performance in the Nordics

\begin{tabular}{|c|c|c|c|c|c|c|}
\hline & Denmark & Finland & Norway & Sweden & UK & NI \\
\hline $\begin{array}{l}\text { GDP per head } \\
(P P P) 2016 \mathrm{EU} \\
\text { average }=100\end{array}$ & 125 & 109 & 149 & 124 & 108 & $79(2015)$ \\
\hline $\begin{array}{l}\text { Unemployment } \\
\text { rate\% (ILO } \\
\text { definition) July } \\
2017\end{array}$ & 5.4 & 8.8 & 4.1 & 7.1 & 4.4 (May) & $\begin{array}{l}4.7 \quad \text { (July- } \\
\text { August) }\end{array}$ \\
\hline $\begin{array}{l}\text { Employment } \\
\text { rate\% (ILO } \\
\text { and Eurostat } \\
\text { definition) } 16- \\
64 \quad \text { year } \\
\text { old(Jan.- } \\
\text { Mar.2013) }\end{array}$ & 72.0 & $\begin{array}{l}\text { 68.5(Oct.- } \\
\text { Dec. 2012) }\end{array}$ & $75.4(2010)$ & 72.9 & 71.4 & 66.7 \\
\hline \multicolumn{7}{|c|}{$\begin{array}{l}\text { Note on sources: GDP comparisons using purchasing power parities. An NI/UK comparison for 2015, } \\
\text { Office for National Statistics (ONS) } 15 \text { December 2016, "Regional GVA (Income Approach)", Statistical } \\
\text { Bulletin, ONS, Newport, is linked to the EU comparisons in Eurostat (1 June 2017). Unemployment rates } \\
\text { comparisons use a comparable ILO based definition in Northern Ireland Statistics and Research Agency } \\
\text { (NISRA) October 2017, Labour Market Report, NISRA, Belfast and ILO. Employment rate using } \\
\text { comparable ILO definitions for the working age population (defined as } 15 \text { to 64), from Northern Ireland } \\
\text { Statistics and Research Agency (NISRA website), www.detini.gov.uk/Ifs_2.11_mm13.xls }\end{array}$} \\
\hline
\end{tabular}


Table 2 : Relative size of public sector employment in the Nordic countries (all employment figures in '000s)

\begin{tabular}{llllllll}
\hline & $\begin{array}{l}\text { Denmark } \\
\mathbf{2 0 0 5}\end{array}$ & $\begin{array}{l}\text { Finland } \\
\mathbf{2 0 0 5}\end{array}$ & Norway2005 & Sweden2005 & UK2005 & UK2011 & NI2011 \\
\hline PSE & 928.4 & 654.0 & 831.6 & 1239.8 & 6107.0 & 6056 & 222 \\
\hline L & 2732.8 & 2421.0 & 2289.0 & 4263.0 & 28166.0 & 29115.4 & 781.7 \\
\hline PSE\%ofL & 34.0 & 27.0 & 36.3 & 29.1 & 21.6 & 20.8 & 28.4
\end{tabular}

PSE: Total public sector employment (including public enterprises and agencies and organisations which are mainly publicly funded).

L: Total number in employment in entire economy.

Note on sources: Comparisons for 2005 based on comparable definition of public sector employment and total employment, from International Labour Organisation (ILO) statistics (ILO website http://laborsta.ilo.orgSTP/guest) except Finland where there was a narrower definition of public sector excluding some public enterprises and also using a national definition of total employment in the case of Denmark. The UK and NI data for 2011 are not necessarily on an entirely comparable basis to the earlier ILO comparisons, the definition of public sector includes those banks subject to public support after 2008; from Office for National Statistics 12 September 2012, "Public sector employment, Q2 2012", Statistical Bulletin, ONS, Newport. It was not possible to breakdown public sector employment by type of activity. 
Table 3: Income (after tax and benefits) inequality in the Nordics compared to the UK, 2010 (Gini coefficients, closer to zero equals more equal, closer to one equals more unequal)

\begin{tabular}{|l|l|}
\hline Country/region & Gini coefficient \\
\hline Norway & 0.25 \\
\hline Denmark & 0.25 \\
\hline Finland & 0.26 \\
\hline Sweden & 0.27 \\
\hline Scotland & 0.30 \\
\hline Northern Ireland & Number not disclosed but indicated as slightly less \\
& than Scotland ${ }^{21}$ \\
\hline UK & 0.34 \\
\hline
\end{tabular}

Source: OECD data. Scotland from Scottish Government November 2013, op.cit. Northern Ireland from Department for Enterprise, Trade and Investment March 2012, Economic Strategy Rebuilding and Rebalancing the Economy: An Evidence Base, Paper to support Executive Economic Strategy, accessed from DETI website, http://www.northernireland.gov.uk/nies-evidence-base-slides-march-2012.pdf, accessed 9 December 2013. 
Table 4: Quality of life/equality indicators and competitiveness measures in the Nordics compared to the UK

\begin{tabular}{|c|c|c|c|c|c|}
\hline & $\begin{array}{l}\text { Quality of } \\
\text { indicators }\end{array}$ & life/equality & Competitivenes & measures (countr & ranking, $1=$ best) \\
\hline Country & $\begin{array}{l}\text { UN }{ }^{\text {HDI }} \\
\text { ranking } \\
(2012)^{*}\end{array}$ & $\begin{array}{l}\text { Gini } \\
\text { coefficient } \\
(2010)\end{array}$ & $\begin{array}{l}\text { Ease of doing } \\
\text { business } \\
(2014)^{* *}\end{array}$ & $\begin{array}{l}\text { IMD } \\
\text { competitiveness } \\
(2013) * * *\end{array}$ & $\begin{array}{l}\text { WEF } \\
\text { competitiveness } \\
(2012-13) * * * *\end{array}$ \\
\hline Denmark & 15 & 0.252 & 5 & 12 & 12 \\
\hline Finland & 21 & 0.26 & 12 & 20 & 3 \\
\hline Norway & 1 & 0.249 & 9 & 6 & 15 \\
\hline Sweden & 7 & 0.269 & 14 & 4 & 4 \\
\hline UK & 26 & 0.341 & 10 & 18 & 8 \\
\hline NI & n.a. & c. 0.3 & n.a. & n.a. & 42 \\
\hline
\end{tabular}

Note: *Human Development Index; weighted average of ranking by GDP (purchasing power parity) per head, educational provision and life expectancy.

**http://www.doingbusiness.org/reports/global-reports/doing-business-2014

***http://www.imd.org/wcc/news-wcy-ranking/

****SQW/Economic Advisory Group/Cambridge Econometrics June 2013, Competitiveness Index for Northern Ireland, EAG, Belfast.

Source: Scottish Government November 2013 
Table 5: The performance of the Nordics' performance compared to the UK in terms of various indicators of business competitiveness, 2011

\begin{tabular}{|l|l|l|l|l|l|}
\hline & $\begin{array}{l}\text { Manufacturing } \\
\text { output as \% of } \\
\text { total GVA }\end{array}$ & $\begin{array}{l}\text { Business } \\
\text { investment as } \\
\text { \% of GDP }\end{array}$ & $\begin{array}{l}\text { Exports as \% } \\
\text { of GDP }\end{array}$ & $\begin{array}{l}\text { Business } \\
\text { R\&D as \% } \\
\text { of GDP }\end{array}$ & $\begin{array}{l}\text { Change in } \\
\text { manufacturing } \\
\text { GVA 1990- } \\
\text { 2011 } \\
\text { (constant } \\
\text { prices) }\end{array}$ \\
\hline Denmark & 10.9 & 10.3 & 53.8 & 2.1 & 11.2 \\
\hline Finland & 17.3 & 9.9 & 40.7 & 2.7 & 105.8 \\
\hline Sweden & 16.8 & 11.9 & 49.9 & 2.3 & 154.7 \\
\hline UK & 10.8 & 8.2 & 32.5 & 1.3 & 2.4 \\
\hline NI & 13 & n.a. & $22(2013)$ & 1.4 & $8.6^{*}$ \\
\hline
\end{tabular}

Note:*Estimated using the relationship which existed between nominal GVA growth in NI and the UK during 1997-2001.

Source: UNCTAD,Eurostat and OECD quoted in Scottish Government November 2013, op.cit. NI from ONS (and UK business R\&D rate), NI export rate from NISRA 14 August 2017,Broad Economy Sales and Export Statistics, NISRA, Belfast and NISRA 7 August 2017, Economics Accounting Project, NISRA, Belfast . 
${ }^{1}$ Furthermore, an earlier study suggested that Bacon and Eltis did not provide a persuasive formulation of labour shortage. During the 1970s the private sector jobs lost were predominately held by male whereas the public sector jobs created were far more likely to be (often part time) females (Stafford, 1981, pp.50-51).

2 At the time of writing (November 2017) there is not a functioning Northern Ireland Executive or Assembly. Yet regardless of whatever political situation emerges, it would be our contention that any genuine attempt at improving regional economic performance should draw on the insights provided here. For more information on the costs and benefits of decentralising taxation in the Northern Irish case see (Budd, 2016; Birnie and Brownlow, 2017). For a discussion of the institutional economics applied to the devolution project in Scotland, Wales and Northern Ireland see (Brownlow, 2017).

3 Although it is often counted as a member of the Nordic club, we have excluded Iceland from our consideration. This is partly because Iceland's population is much smaller than that of the other four countries and smaller even than NI. Its population of 300,000 is similar to that of the city of Belfast. Iceland had a very favourable economic performance until the downturn in 2008 followed by an extremely sharp recession; both driven in part by a financial sector which was very large compared to domestic GDP.

${ }^{4}$ Hayek certainly cannot be claimed to be an ideological advocate for economic interventionism. Famously, during the calculation debate Hayek demonstrated the epistemic impossibilities of successful socialist economic planning (Butler 1983; Gray 1998, 146-61). However, even one of his most perceptive critics acknowledges that Hayek's social scientific writings must be distinguished from his more ideological writings (Gamble 1996).

${ }^{5}$ Hayek rejected passive government or laissez faire, which he equated with non-intervention, as he thought it provided an inadequate criterion for distinguishing between appropriate and inappropriate interventions (Hayek 1960, 231; Miller 2010, 138).As Miller summarises Hayek's argument in this regard, 'an active government that assists the spontaneous forces of the market is preferable to a less active one that does the wrong things' (Miller 2010, 138).

${ }^{6}$ For instance, Hayek argued that correcting informational problems as well as providing monetary stability were areas that government could usefully support economic activity (Hayek 1960, 223). Some areas of health and safety legislation were also placed in this category (Hayek 1960, 225). Hayek likewise opposed price regulation because it would have to be discretionary and arbitrary rather than grounded in rules (Hayek 1960, 228).

8 Another argument was part of public spending was used to compensate for and in effect fossilise inefficiency in the production side of the economy and especially manufacturing (Hitchens, Wagner and Birnie 1990). Crafts (1995), in a pioneering empirical piece, demonstrated that the X-inefficiency, which a high level of public spending encouraged, was an important component in explaining why NI's trend rate of economic growth between 1945 and 1973 was less than that which would otherwise have been expected.

9 It should be clear to the interested reader that the Eltis and Bacon model was originally devised to explain macroeconomic rather that regional problems. A referee suggested that public projects pay better than private ones, so government contracts could in principle 'crowd out' resources that otherwise dedicated to private activities, Hence a decline of firms dependent upon public contracts would lead capital to reallocate rewards towards a more private sector-based economy. While a theoretically interesting argument it is difficult to see how this could be tested in the NI case: we don't have otherwise identical contracts to compare and the fact that the economy is dominated by privately owned family firms means that we are limited the information we have concerning capital allocation.

${ }^{10}$ The negative economic effects of peripheral location (particularly in its 'softer' form) could be placed in this category. Soft peripherality is claimed to be associated with cumulative causation as initial disadvantage can breed long-term disadvantage (Birnie and Hitchens 1999). Likewise, during the Troubles the economic 
implications of civil unrest further damaged an already fragile regional economy. It is important to note that that economy was already underperforming prior to the outbreak of violence (Rowthorn 1981; Brownlow 2012; 2013).

${ }^{11}$ The apex of state planning was the publication in 1976 of the Quigley Report which advocated the pursuit of a regional industrial policy led by civil servants involving a high degree of state intervention aimed at industrial development (Quigley 1976).

${ }^{12}$ In 2011 NI regional output or gross value added (GVA) totalled $£ 29.4 \mathrm{bn}$. In the same year total public spending in NI (including NI’s share of certain UK-wide expenditures) was about $£ 22.4 \mathrm{bn}$, i.e. equivalent to about three-quarters of the total output of the region.

${ }^{13}$ A note of caution at this point, while the long-run performance of the Nordics have been impressive, it is noteworthy that while between 2008 and 2014, Sweden, Norway and Denmark all recovered from the global financial crisis, albeit with differing degrees of success, Finland remained mired in recession with its economy in 2014 remaining around 6\% lower than its 2008 level. Country-specific factors, such as its greater economic exposure to Russia and its policymaker's more serious pursuit of austere macroeconomic policies, have been invoked to explain why Finland's economic performance has diverged from the rest of the Nordics (Hinds and Hollingsworth, 2014).

${ }^{14}$ Where a value of zero indicates absolute equality and a value of one extreme inequality.

${ }^{15}$ See, for example, Childs (1947).

${ }^{16}$ Moreover, of relevance to the importance of Rodrik's thesis, there is some empirical evidence linking flexicurity to his finding that social insurance may be greater in countries more exposed to international competition (Boeri, Galasso and Conde-Ruiz, 2012, 703).

${ }^{17}$ This may have been because the devolved administrations in the UK have so far been concerned mainly with making decisions about spending without a corresponding responsibility to make a decision about how such spending is funded. Policies relating to distributional matters have arguably been given priority relative to those which might promote economic growth. In other words, politicians within devolved settings are particularly susceptible to lobbying that leads to higher public expenditure. Such a finding has echoes in those who have previously written about the economic dividend of devolution (Rodríguez-Pose and Gill, 2005).

${ }^{18}$ It is noted that the employment rate amongst native born Swedes is $84 \%$ compared to $51 \%$ amongst nonEuropeans in Sweden. By implication, the Nordics are not immune to some of the social problems felt elsewhere.

${ }^{19}$ Such collaboration being directed at the highest political level; the Research Innovation Council is chaired by the Prime Minister. There is an active innovation promotion agency; Tekes. Alongside this there is a strong publicly funded research body, the VTT, which, significantly, sits outside of the universities and also charges businesses for its services.

${ }^{20}$ (Department of Finance and Personnel, 2012). According to that source the transfer in 2010-11 was about $£ 10 \mathrm{bn}$.

${ }^{21}$ One earlier study using the Family Expenditure Survey data indicated a Gini coefficient of 0.34 for disposable income in NI in 2001/2 (V.Gribben December 2002, Evaluation of the New TSN: Gini Coefficient Analysis, OFM DFM Equality Directorate Research Branch, Belfast, accessed from http://www.ofmdfmni.gov.uk/gini.pdf, [9 December 2013]. An even earlier study indicated that the Gini coefficients for NI and GB were almost identical in the 1980s albeit comparison was difficult because the graph lines of the cumulative \% of income earned by decile ("the Lorenz curves") for NI and GB crossed over; See (McGregor and Borooah 1991). 